\title{
GRAFTING OF CHLOROACETIC ACID ON EGDE CROSS-LINKED CHITOSAN TO ENHANCE STABILITY AND ADSORPTION CAPACITY FOR Pb(II) IONS
}

\author{
Abu Masykur ${ }^{1, *}$, Sri Juari Santosa ${ }^{2}$, Dwi Siswanta ${ }^{2}$, and Jumina ${ }^{2}$ \\ ${ }^{1}$ Department of Chemistry, Faculty of Mathematics and Natural Sciences, Sebelas Maret University, \\ JI. Ir. Sutami 36A Surakarta 57126, Indonesia \\ ${ }^{2}$ Department of Chemistry, Faculty of Mathematics and Natural Sciences, Universitas Gadjah Mada, \\ Sekip Utara Kotak Pos BLS 21, Yogyakarta 55281, Indonesia
}

Received August 2, 2013; Accepted December 11, 2013

\begin{abstract}
The aims of this research is to synthesize a chitosan derivative insoluble in acidic aqueous medium and that has high adsorption capacity for $\mathrm{Pb}(\mathrm{II})$ ions by cross-linking and grafting. Cross-linking and grafting were done using ethylene glycol diglycidyl ether (EGDE) and chloroacetic acid, respectively. The modified chitosan was characterized using FTIR spectrophotometer, XRD and TG-DTA. Chitosan and Chit-EGDE-Acetate was applied as adsorbent of $\mathrm{Pb}(\mathrm{II})$ ions in a batch system. The concentration of $\mathrm{Pb}(\mathrm{II})$ in adsorption medium was quantified using AAS. The result showed that the adsorption was optimum at pH 5, contact time of 200 min for chitosan and 300 min for Chit-EGDEAcetate. Adsorption of $\mathrm{Pb}(\mathrm{II})$ ions on both adsorbents followed pseudo second order kinetic equation. Adsorption of $\mathrm{Pb}$ (II) ions on chitosan followed Freundlich isotherm while that on Chit-EGDE-Acetate followed the Langmuir adsorption isotherm. The adsorption capacity of Chit-EGDE-Acetate for $\mathrm{Pb}(\mathrm{II})$ ions was $200.0 \mathrm{mg} \mathrm{L}^{-1}$ while that for chitosan was $166.7 \mathrm{mg} \mathrm{L}^{-1}$. Interaction type of $\mathrm{Pb}(\mathrm{II})$ ions on adsorbent was determined by sequential desorption.
\end{abstract}

Keywords: chitosan; EGDE; chloroacetic acid; adsorption; Pb(II)

\begin{abstract}
ABSTRAK
Tujuan penelitian ini adalah melakukan sintesis turunan kitosan yang tidak larut dalam medium asam dan mempunyai kemampuan adsorpsi ion $\mathrm{Pb}(\mathrm{II})$ yang tinggi dengan cara penautan-silang dan pencangkokan. Etilen glikol diglisidil eter (EGDE) digunakan sebagai reagen penaut-silang dan asam kloroasetat sebagai reagen pencangkokan. Kitosan dan hasil modifikasinya (Kit-EGDE-Asetat) dianalisis dengan spektrofotometer FTIR, XRD dan TG-DTA kemudian diaplikasikan sebagai adsorben ion $\mathrm{Pb}(\mathrm{II})$. Konsentrasi $\mathrm{Pb}(\mathrm{II})$ dalam larutan dianalisis dengan SAA. Hasil penelitian menunjukkan adsorpsi optimum terjadi pada pH 5, waktu kontak 200,0 menit untuk kitosan dan 300 menit untuk Kit-EGDE-Asetat. Adsorpsi ion Pb(II) pada kedua adsorben mengikuti persamaan kinetika pseudo orde-dua. Adsorpsi ion Pb(II) pada kitosan mengikuti isoterm adsorpsi Freundlich sedangkan pada Kit-EGDE-Asetat mengikuti isoterm adsorpsi Langmuir. Kapasitas adsorpsi Pb(II) pada Kit-EGDE-Asetat adalah $200,0 \mathrm{mg} \mathrm{L}^{-1}$ sedangkan pada kitosan 166,7 $\mathrm{mg} \mathrm{L}^{-1}$. Interaksi Pb(II) pada adsorben ditentukan dengan desorpsi sekuensial.
\end{abstract}

Kata Kunci: kitosan; EGDE; asam kloroasetat; adsorpsi; $P b(I I)$

\section{INTRODUCTION}

Water pollution by chemicals is a problem throughout the world. Heavy metal ions are one of the most dangerous pollutants because they are typically very toxic even in small concentrations [1-2]. Lead $(\mathrm{Pb})$ is one of the heavy metal that is usually found in wastewater. It is widely used in industries of the smelting of iron and steel, battery, the metal coating, paint, color/textile, and electrical wiring. Lead is widely used also as fuel additive [2-3].

\footnotetext{
* Corresponding author. Tel/Fax : +62-8170443071
}

Email address : abu.masykur@gmail.com
Chemical and physical processes that can be potentially used to remove toxic metal ions in water include ion-exchange, reverse osmosis, liquid extraction, electrolysis, adsorption, complexation, and precipitation. Among the others, adsorption is a process which get increasingly attention because it is generally simple, inexpensive, and able to reduce metal ions until a very low concentrations [2-3]. The development of adsorbent that is inexpensive and have a high adsorption capacity is the main goal of many research works. One of interesting studies is the use of biomaterials as adsorbents for metal ions waste [3-4].

Abu Masykur et al. 
Biomaterials is very important because it is cheap and biodegradable, such materials may be derived from agricultural waste (corn husk, bagase, rice husk, lignin, or other sources), microbial biomass and chitosan [5-6].

Chitosan is one of the prospective materials to be developed as an adsorbent. Chitosan is known to have an excellent ability as an adsorbent of metal ions. The presence of the amine group at position $\mathrm{C} 2$ and the hydroxyl group at position C3 of 2-deoxy-D-glucose make chitosan is able to form chelates with almost all metal ions [7]. Amine and hydroxyl groups in chitosan also allows for modification of chitosan [3]. Unfortunately, chitosan has several disadvantages when used directly as an adsor bent such as its solubility in acidic solution, prone to swelling, unsatisfactory mechanical properties and small adsorption capacity for certain metal ions [3]. To overcome these problems, chitosan can be modified by cross-linking to make chitosan that is stable in acid and has good mechanical properties. Though cross-linking reduces the adsorption capacity, but it will increase the stability of the polymer [8]. Stability is very important when used in the industry [9]. The problem of decreasing adsorption capacity after cross-linking can be solved by grafting certain functional group on chitosan. The cross-linking procedure may be performed by reaction of chitosan with different reagent such as epichlorhydrin (ECH) [10-12] glutaraldehyde (GLA) $[13,14]$ and EGDE (15-17]. As GLA and EGDE tends to cross-link chitosan bonding through the amino groups and $\mathrm{ECH}$ does it preferably through the hydroxyl groups, it is possible to understand the adsorption mechanism [18-20].

In this research, chitosan is cross-linked using EGDE on the hydroxyl group followed by grafting the amine group using chloroacetic acid. Cross-linking of chitosan using EGDE produced modified chitosan that was not soluble in acid and had good mechanical properties [7,16-17]. Grafting chitosan with chloroacetic increased the number of active groups thus increasing the adsorption capacity of chitosan [21-22]. Modified chitosan obtained in this research was then used as an adsorbent of $\mathrm{Pb}(\mathrm{II})$ ions. Effect of solution $\mathrm{pH}$, contact time, and the initial concentration of $\mathrm{Pb}$ (II) have been examined. Moreover, desorption processes were studied in this research.

\section{EXPERIMENTAL SECTION}

\section{Materials}

Chitosan with the deacetylation degree in the range of $75-85 \%$ and ethylene glycol diglycidyl ether (EGDE) were purchased from Sigma Aldrich (Germany). Benzaldehyde, ethanol, sodium hydroxyde pellet, 1,4 dioxane, monochloroacetic acid, n-propanol, $\mathrm{HCl} 37 \%$, fumed $\mathrm{HNO}_{3}, \mathrm{~Pb}\left(\mathrm{NO}_{3}\right), \mathrm{Na}_{2} \mathrm{EDTA}$, and $\mathrm{KNO}_{3}$ were purchased from $E$ Merck (Germany). Double distillate water was obtained from Chemistry Laboratories UGM.

\section{Instrumentation}

Instruments used in this study were consisted of $\mathrm{pH}$ meter (TOA HM-30R), Shaker (Marus Instrumenten), Oven (Heraeus), AAS (Perkin Elmer 3110), analytical balance (Mettler Toledo AB54-S), FTIR Spectrophotometer (Shimadzu 8201PC), XRD (Shimadzu XRD-6000) and TG-DTA (ThermoPLUS Evo RigakuT 8120)

\section{Procedure}

\section{Modification chitosan}

Cross-linked chitosan was synthesized using procedure that was reported by Oshita et al. [15]. Chitosan $(4.0 \mathrm{~g})$ was dispersed in $40 \mathrm{~mL}$ ethanol, added $16 \mathrm{~mL}$ benzaldehyde and stirred for overnight. The mixture was filtered and washed with ethanol to remove unreacted benzaldehyde to obtain benzaldehyde-protected chitosan (Chit-Ben). The obtained Chit-Ben was put in a round flask containing $60 \mathrm{~mL}$ of dioxane and then added $8 \mathrm{~mL}$ of $1 \mathrm{M} \mathrm{NaOH}$ and $4.296 \mathrm{~g}$ EGDE. Mixture was refluxed for $6 \mathrm{~h}$. The mixture was washed by ethanol and distilled water until neutral $\mathrm{pH}$ to obtain Chit-Ben-BADGE. Benzaldehyde was released from the amine group by stirring in $200 \mathrm{~mL}$ of $0.5 \mathrm{HCl}$ for $15 \mathrm{~h}$, and this process was done twice to obtain Chit-EGDE. Chit-EGDE was washed with ethanol and water to remove any remaining benzaldehyde and EGDE. Chit-EGDE was then grafted using chloroacetic following the procedure reported by Abreou and Campana-Fihlo [23]. Chit-EGDE was suspended in $80 \mathrm{~mL}$ isopropanol and stirred for $20 \mathrm{~min}$ and then added $28 \mathrm{~mL}$ of $40 \% \mathrm{NaOH}$ dropwise. Chloroacetic acid $(124 \mathrm{~mL})$ in isopropanol $(2 \mathrm{M})$ was added dropwise in the mixture and stirred for $15 \mathrm{~h}$. Mixture was neutralized using acetic acid and washed with water and ethanol and then dried in an oven to obtain Chit-EGDE-Acetate.

\section{Characterization}

Chitosan and its derivatives were analyzed by FTIR spectrophotomether using $\mathrm{KBr}$ pellet method on wave numbers between $400-4000 \mathrm{~cm}^{-1}$. TG-DTA was done at temperature between $30-600{ }^{\circ} \mathrm{C}$ in air atmosphere with increasing temperature rates of $10{ }^{\circ} \mathrm{C} / \mathrm{sec}$. XRD analysis was done with powder method at $2 \theta$ from $5-60^{\circ}$. 


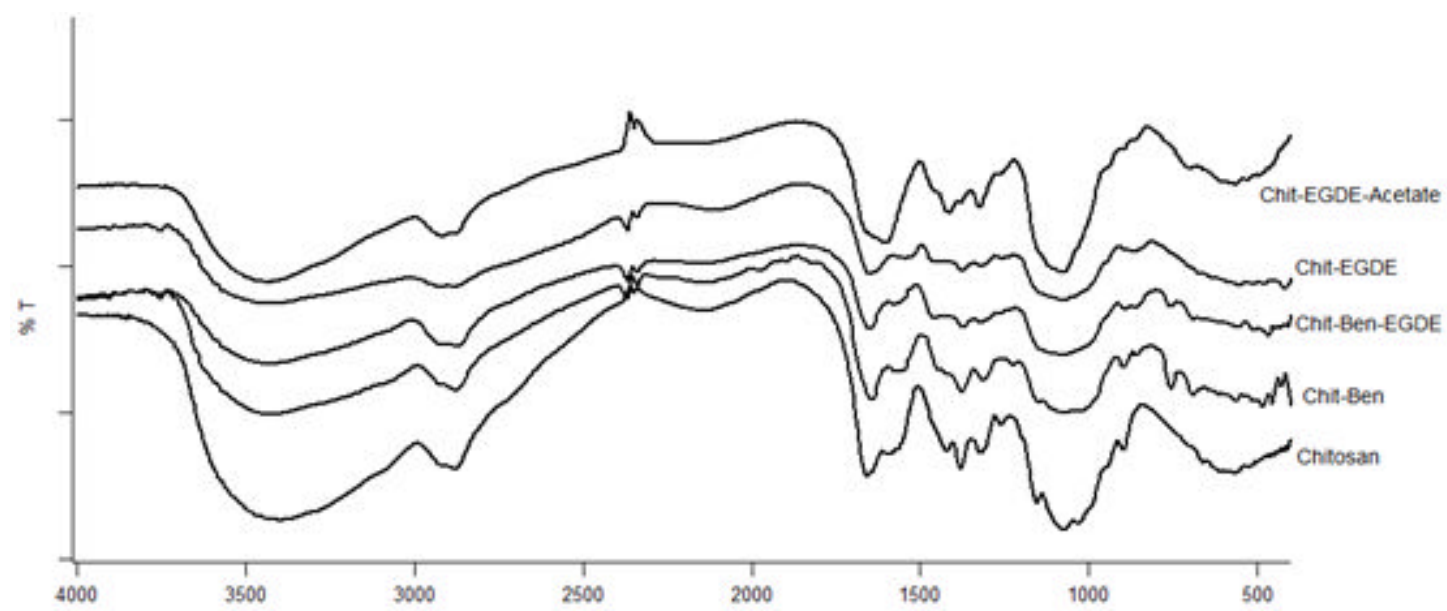

Fig 1. FTIR spectra of chitosan, Chit-Ben, Chit-Ben-EGDE, Chit-EGDE and Chit-EGDE-Acetate

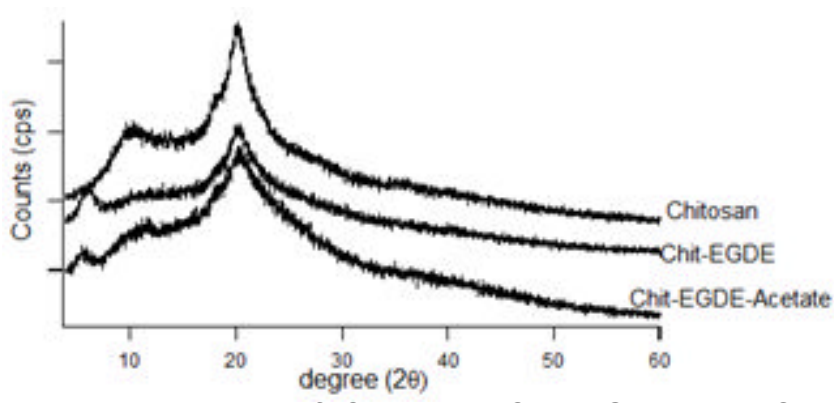

Fig 2. XRD patern of Chitosan, Chit-EGDE and ChitEGDE-Acetate

\section{Adsorption experiment}

Adsorption properties of chitosan and Chit-EGDEAcetate for $\mathrm{Pb}(\mathrm{II})$ ions were studied by a batch technique. A series of $25 \mathrm{~mL}$ of $150 \mathrm{ppm} \mathrm{Pb}$ (II) solutions with their acidities were adjusted to $\mathrm{pH} 2.0$ to 6.0 by adding $\mathrm{HNO}_{3}$ or $\mathrm{NaOH}$ was placed in the bottles containing $15.0 \mathrm{mg}$ of adsorbent and shaked for $20 \mathrm{~h}$ at $40 \mathrm{rpm}$. The mixture was filtered with Whatman filter paper no. 42. The concentration of remaining $\mathrm{Pb}(\mathrm{II})$ ions in solution is quantified by AAS. The content of metal ions adsorbed was calculated by the equation:

$\mathrm{Q}=\left[\left(\mathrm{C}_{\mathrm{o}}-\mathrm{C}_{\mathrm{e}}\right) \mathrm{V}\right] /(\mathrm{m})$

where $Q$ is the amount of metal ions adsorbed in each gram of adsorbent $\left(\mathrm{mmol} \mathrm{g}{ }^{-1}\right), C_{0}$ and $C_{e}$ are the concentration of metal ions before and after adsorption $\left(\mathrm{mmol} \mathrm{L}^{-1}\right)$ respectively, $\mathrm{V}$ is the solution volume $(\mathrm{mL})$, and $\mathrm{m}$ is the weight of adsorbent $(\mathrm{g})$.

Variation of the contact time between 0 to $800 \mathrm{~min}$ conducted to examine the adsorption kinetics. Variation of concentration was performed to determine the type of adsorption isotherms using concentration $\mathrm{Pb}(\mathrm{II})$ in the range 0 to 500 ppm. Type of interaction between $\mathrm{Pb}$ (II) and the adsorbent was elucidated by performing sequential desorption of adsorbed $\mathrm{Pb}$ (II) in water, $\mathrm{KNO}_{3}$ $(0.1 \mathrm{M}), \mathrm{HNO}_{3}(0.1 \mathrm{M})$ and $0.1 \mathrm{M} \mathrm{Na}_{2} \mathrm{EDTA}$, respectively [24].

\section{RESULT AND DISCUSSION}

\section{Characterization Materials}

Modification of chitosan was begun with a crosslinking chitosan by EGDE through its hydroxyl groups. To protect the involvement of amine group of chitosan on the cross-linking, this group was first protected with benzaldehyde through Sciff base reaction. Chitosan which has been protected was cross-linked using EGDE as cross-linker through the hydroxyl groups of chitosan and the benzaldehyde was then released from the amine group of chitosan by stirring the protected and cross-linked chitosan in the solution of $0.5 \mathrm{M} \mathrm{HCl}$. The amine group free from its interaction with benzaldehyde was then grafted with chloroacetic in npropanol solution. Modified chitosans was conducted by FTIR spectrophotometer, XRD and TG-DTA.

As shown in the spectra of chitosan and modified chitosan (Fig. 1) the peaks at $3335 \mathrm{~cm}^{-1}$ assigned to the stretching vibration of $-\mathrm{OH}$ and $-\mathrm{NH}$ groups. The peak at $2868 \mathrm{~cm}^{-1}$ is due to $-\mathrm{CH}$ stretching vibration of $-\mathrm{CH}$ and $\mathrm{CH}_{2}$. The peak at $1635 \mathrm{~cm}^{-1}$ is characteristic vibration of $\mathrm{C}=\mathrm{O}$ from amide, that is overlap with $\mathrm{NH}$ vibration from amine group at $1592 \mathrm{~cm}^{-1}$. Protection of benzaldehyde (Chit-Ben) generated new peaks at $763 \mathrm{~cm}^{-1}$ and $702 \mathrm{~cm}^{-1}$ indicate the symmetry and asymmetry stretching vibration of monosubstitued benzene. The peak at $1592 \mathrm{~cm}^{-1}$ disappeared due to reaction amine group with benzaldehyde [25]. The cross-linked chitosan (Chit-Ben EGDE) showed increasing peak at $1100 \mathrm{~cm}^{-1}$ that is the $-\mathrm{CO}$ stretching vibration of EGDE. Deprotection of amine group from benzadehyde (Chit-EGDE) was shown from disappearance of peak at763 $\mathrm{cm}^{-1}$ and $702 \mathrm{~cm}^{-1}$, and increasing peak at $1592 \mathrm{~cm}^{-1}$ of the amine group. Infrared spectra of Chit-EGDE-Acetate was characterized by the presence of new peak at $1600 \mathrm{~cm}^{-1}$ 

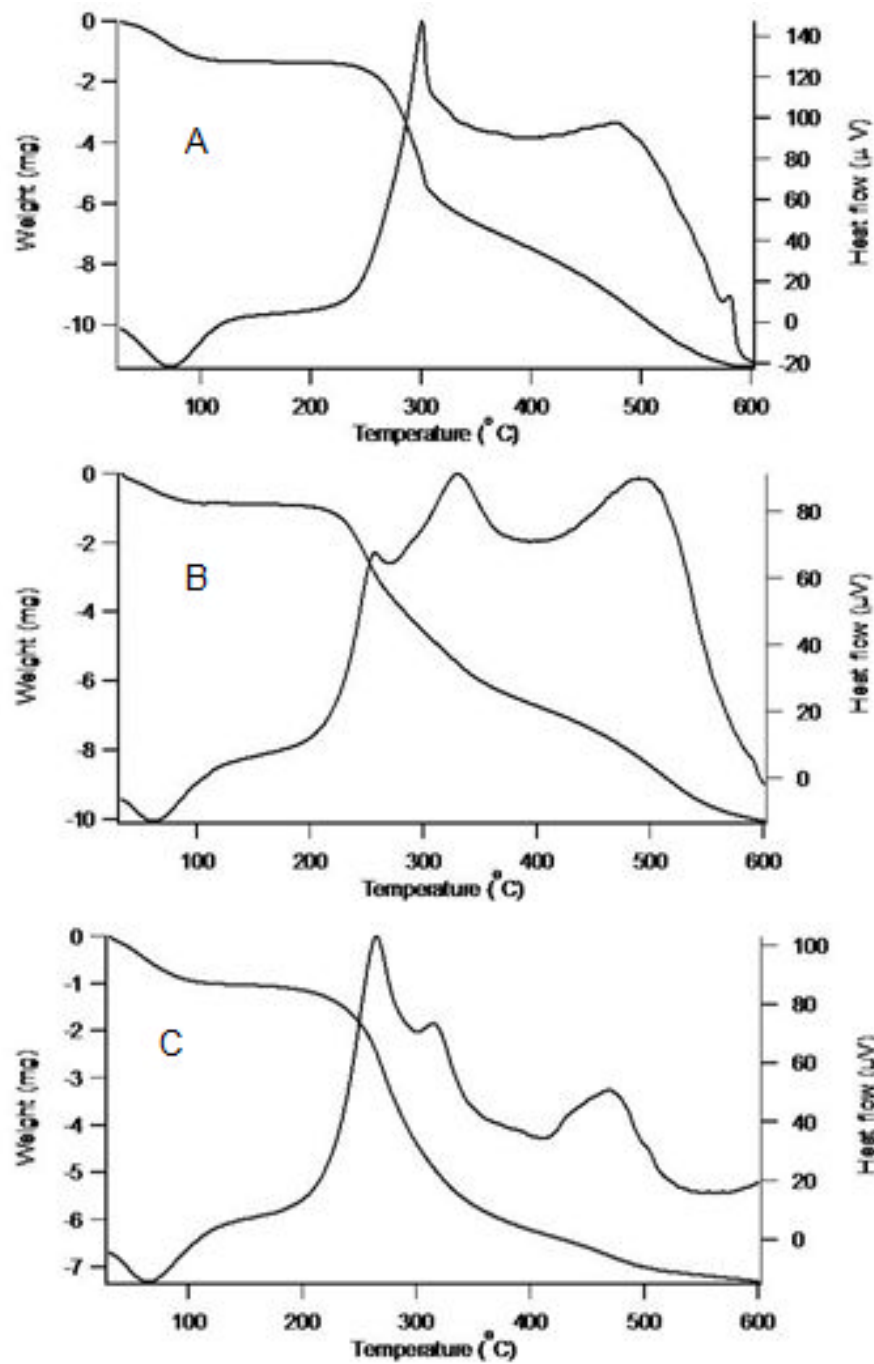

Fig 3. TG-DTA of chitosan (A), Chit-EGDE (B) and ChitEGDE-Acetate (C)

is assigned to $-\mathrm{COO}^{-}$. Intensity peak at $1400 \mathrm{~cm}^{-1}$ increased, this is related to increasing ethylene group of carboxymethyl [21,26-27]

XRD diffractogram of chitosan, Chit-EGDE and Chit-EGDE-Acetate were shown in Fig. 2. XRD pattern of chitosan showed typical peaks at an angle $(2 \theta)$ of $10^{\circ}$ and $20^{\circ}$ degrees [28]. Cross-linking processes made decreasing crystallinity of chitosan as indicated by the weakening of the peak at $10^{\circ}$ and $20^{\circ}$ [29]. Distance between chitosan chains was increased because of modification indicating that the hydrogen bonding weaken [30]. The new peak at $2 \theta \approx 6^{\circ}$ was caused by the formation of a new bond between the chitosan chains. Chloroacetic grafting on the chitosan-crosslinked increased peaks at $2 \theta \approx 20^{\circ}$, this was due to the formation of new hydrogen bonding and formed a more organized structure.

\section{Thermal Analysis}

Chitosan, Chit-EGDE, and Chit-EGDE-Acetate were studied their thermal properties at a temperature 30-600 ${ }^{\circ} \mathrm{C}$ using TG-DTA and their thermogram are shown in Fig. 3. Thermogram TG-DTA of chitosan showed thermal degradation at three stages, the first stage was at temperature $65-110{ }^{\circ} \mathrm{C}$, with a weight reduction of $11 \%$. This is an endothermic reaction due to water elimination which adsorbed physically to the chitosan. The second stage was the exothermic reaction start at a temperature $271-303{ }^{\circ} \mathrm{C}$ with a $50 \%$ weight loss. This is an exothermic reaction, indicated the initial degradation of chitosan, especially the functional groups attached to the main chain of chitosan. The third stage was the exothermic reaction that occurs at a temperature $303-600{ }^{\circ} \mathrm{C}$ with $34 \%$ weight reduction. This is related to the further degradation of the polymer chitosan into water, $\mathrm{CO}_{2}$ and other gases [29].

Analysis of TG-DTA of Chit-EGDE produced thermal degradation at four stages. The first stage was the same as occurs as in the chitosan with $8 \%$ weight loss. In the second stage was initial degradation at temperature $195-268{ }^{\circ} \mathrm{C}$. This temperature is lower than on the chitosan due to the weaker hydrogen bonds in the chitosan cross-linked [31]. The third stage at temperature $268-385{ }^{\circ} \mathrm{C}$ with $30 \%$ weight loss. This exothermic peak associated with degradation of crosslingker EGDE and the main chain of chitosan. The fourth stage was the further degradation that occurs at temperatures above $400{ }^{\circ} \mathrm{C}$ produced water, $\mathrm{CO}_{2}$ and other small gas compounds. Chloroacetic grafting on the chitosan cross-linked showed thermal degradation at four stages. The first stage was elimination water adsorbed on the Chit-EGDE-Acetate at temperature $40-110{ }^{\circ} \mathrm{C}$ with a $10 \%$ weight reduction. The second stage was height peak at $190-297^{\circ} \mathrm{C}$ with $31 \%$ weight reduction. This peak is exothermic reaction due to degradation carboxylate group and another group attached on chitosan chain. The next stage was degradation of cross-linker and glycoside bond of chitosan at temperature $297-405{ }^{\circ} \mathrm{C}$, with $19 \%$ weight loss. Further degradation occurs at temperatures above $400{ }^{\circ} \mathrm{C}$ with $9 \%$ weight loss. Up to a given temperature $\left(600{ }^{\circ} \mathrm{C}\right)$, the remaining $30 \%$ of material Chit-EGDE-Acetate was not completely degraded. This is probably due to grafting of acetate group produces polymer that is more resistant to heat. From the TGDTA, it is clear that cross-linking and grafting processes increase the thermal stability of chitosan. 
Table 1. Kinetic parameter for $\mathrm{Pb}$ (II) adsorption onto Chitosan and Chit-EGDE-Acetate

\begin{tabular}{|c|c|c|c|c|c|c|}
\hline \multirow{3}{*}{ Adsorbent } & \multicolumn{6}{|c|}{ Parameters } \\
\hline & \multicolumn{3}{|c|}{ Pseudo-order 1} & \multicolumn{3}{|c|}{ Pseudo-order 2} \\
\hline & $\begin{array}{c}\mathrm{q}_{\mathrm{e} 1} \\
\left(\mathrm{mmol} \mathrm{g}^{-1}\right)\end{array}$ & $\begin{array}{c}\mathrm{k}_{1} \\
\left(\mathrm{~L} \min ^{-1}\right)\end{array}$ & $\mathrm{R}^{2}$ & $\begin{array}{c}\mathrm{q}_{\mathrm{e} 2} \\
\left(\mathrm{mmol} \mathrm{g}^{-1}\right)\end{array}$ & $\begin{array}{c}\mathrm{k}_{2} \\
\left(\mathrm{~g} \mathrm{mmol}^{-1} \mathrm{~min}^{-1}\right)\end{array}$ & $\mathrm{R}^{2}$ \\
\hline Chitosan & 0.188 & 0.0230 & 0.823 & 0.379 & 0.699 & 0.988 \\
\hline Chit-EGDE-Acetate & 0.268 & 0.0069 & 0.981 & 0.538 & 0.089 & 0.999 \\
\hline
\end{tabular}

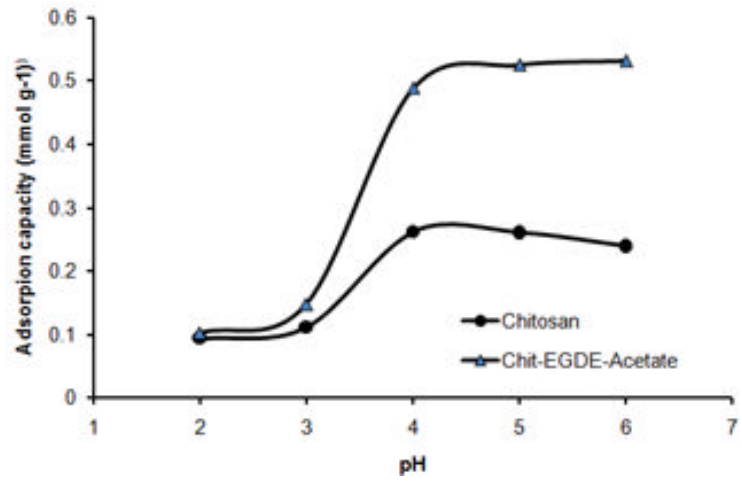

Fig 4. Effect of $\mathrm{pH}$ on the adsorption of $\mathrm{Pb}(\mathrm{II})$ ion by Chitosan and Chit-EGDE-Acetate

\section{Effect of $\mathrm{pH}$ on $\mathrm{Pb}$ (II) Adsorption}

Effect of solution $\mathrm{pH}$ on the adsorption ability of $\mathrm{Pb}$ (II) by chitosan and Chit-EGDE-Acetate was shown in Fig. 4. At lower $\mathrm{pH}(\mathrm{pH} 2$ and 3 ) adsorption was very small, because the partial protonation of the functional groups of chitosan and Chit-EGDE-Acetate. $\mathrm{Pb}(\mathrm{II})$ has positive charge so the electrostatic repulsion happening between metal ions and adsorbent. With the increase of $\mathrm{pH}$ value $(\mathrm{pH} 4-6)$ made functional group have negative charge and able to bind metal ions. In the higher $\mathrm{pH}$, $\mathrm{Pb}(\mathrm{II})$ ions precipitated become $\mathrm{Pb}(\mathrm{OH})_{2}$ that can't be adsorbed and therefore the adsorption ability decrease because adsorption process takes place simultaneously with the precipitation process. Adsorption ability of ChitEGDE-Acetate at each $\mathrm{pH}$ was higher than chitosan, this is may be due to the presence of carboxylate groups wich has high affinity toward $\mathrm{Pb}(\mathrm{II})$. Another advantage of the modified, was the material was insoluble in acidic solution so separation process adsorbent with the solution to be easy.

\section{Adsorption Kinetics}

Effect of contact time on the adsorption of $\mathrm{Pb}$ (II) ions by chitosan and Chit-EGDE-Acetate was shown in Fig. 5. Initially, adsorption increased rapidly due to many active sites of the adsorbent are still empty so bind $\mathrm{Pb}$ (II) ions quickly. When contact time increases, active sites on the adsorbent surface gradually filled and speed of adsorption decreases and eventually adsorption ability will be constant. At this time, active sites bound to $\mathrm{Pb}$ (II)

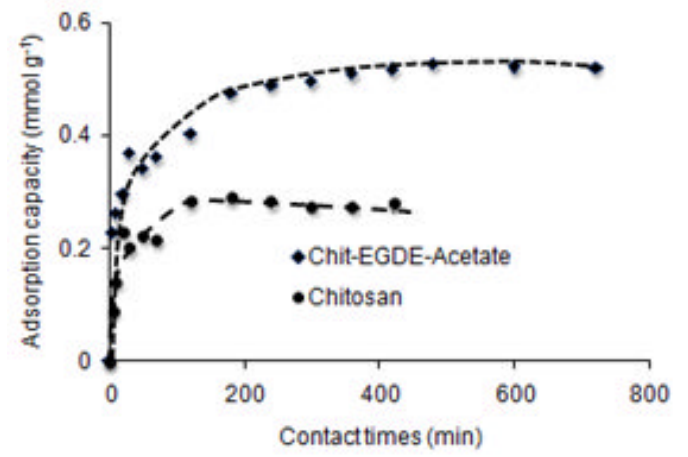

Fig 5. Effect of contact time on the adsorption $\mathrm{Pb}$ (II) by chitosan and Chit-EGDE-Acetate

are maximum. Chitosan has active site amine and hydroxyl groups, while Chit-EGDE-Acetate besides have amine and hydroxyl groups, it is also rich with carboxylate group. Adsorption $\mathrm{Pb}$ (II) ions on ChitEGDE-Acetate was higher than chitosan.

Adsorption kinetic was studied by modeling the data into pseudo first-order kinetics equation (Lagergren) and pseudo second order kinetics equation $(\mathrm{Ho})$ [32]. Pseudo first-order kinetics equation is formulated as:

$\ln \left(q_{e}-q_{t}\right)=\ln \left(q_{e}\right)-k_{1} t$

where $\mathrm{q}_{\mathrm{e}}$ and $\mathrm{q}_{\mathrm{t}}$ are the sorption capacity at equilibrium and at time $\mathrm{t}\left(\mathrm{mmol} \mathrm{g}^{-1}\right)$ and $\mathrm{k}_{1}$ is a pseudo first order rate constants $1\left(\mathrm{~min}^{-1}\right)$.

Pseudo second order kinetic equations is formulated by:

$\frac{t}{q_{t}}=\frac{1}{k_{2} q_{e}^{2}}+\frac{1}{q_{e}} \mathrm{t}$

where $\mathrm{k}_{2}\left(\mathrm{~g} \mathrm{mmol}^{-1} \mathrm{~min}^{-1}\right)$ is a pseudo second order constant.

Parameter of pseudo first order adsorption kinetics and pseudo second order for the sorption of $\mathrm{P}(\mathrm{II})$ ions onto Chitosan and Chit-EGDE-Acetate are shown in Table 1. Adsorption kinetic of $\mathrm{Pb}(\mathrm{II})$ ions on chitosan and Chit-EGDE-Acetate followed pseudo second order kinetics based on correlation coefficient value $\left(R^{2}\right)$. $R^{2}$ for pseudo second order kinetic is higher than $R^{2}$ for pseudo first order kinetic. Pseudo second order kinetics required that the adsorption processes is controlled by chemical bonding between adsorbent and adsorbat, but as shown in eq.3. $q_{t}$ and $q_{e}$ are the only parameters involved. 
Table 2. Parameters of Langmuir and Freundlich isotherm

\begin{tabular}{|c|c|c|c|c|c|c|c|}
\hline \multirow{3}{*}{ Adsorbent } & & \multicolumn{6}{|c|}{ Parameters } \\
\hline & & \multicolumn{3}{|c|}{ Langmuir } & \multicolumn{3}{|c|}{ Freundlich } \\
\hline & $\begin{array}{c}\mathrm{b} \\
\left(\mathrm{mmol} \mathrm{g}^{-1}\right)\end{array}$ & $\begin{array}{c}\mathrm{K} \\
\left(\mathrm{L} \mathrm{mmol}^{-1}\right)\end{array}$ & $\begin{array}{c}\Delta \mathrm{G} \\
\left(\mathrm{KJ} \mathrm{mol}^{-1}\right)\end{array}$ & $\mathrm{R}^{2}$ & $\mathrm{~N}$ & $\begin{array}{c}\mathrm{Kf} \\
\left(\mathrm{mmol} \mathrm{g}^{-1}\right)\end{array}$ & $\mathrm{R}^{2}$ \\
\hline Chitosan & 0.778 & 0.938 & 17.240 & 0.713 & 2.042 & 0.385 & 0.868 \\
\hline Chit-EGDE-Acetate & 0.789 & 8.867 & 22.899 & 0.979 & 1.292 & 0.142 & 0.823 \\
\hline
\end{tabular}

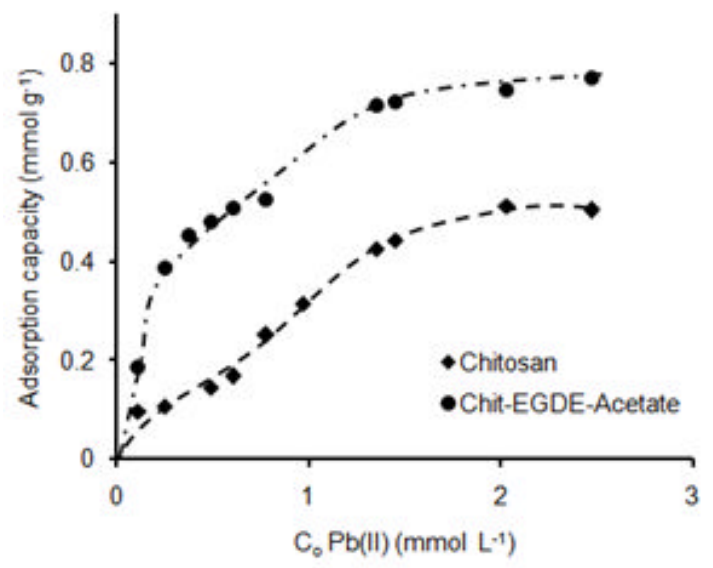

Fig 6. Effect of initial concentration on adsorption of $\mathrm{Pb}$ (II) by chitosan and chitosan modified

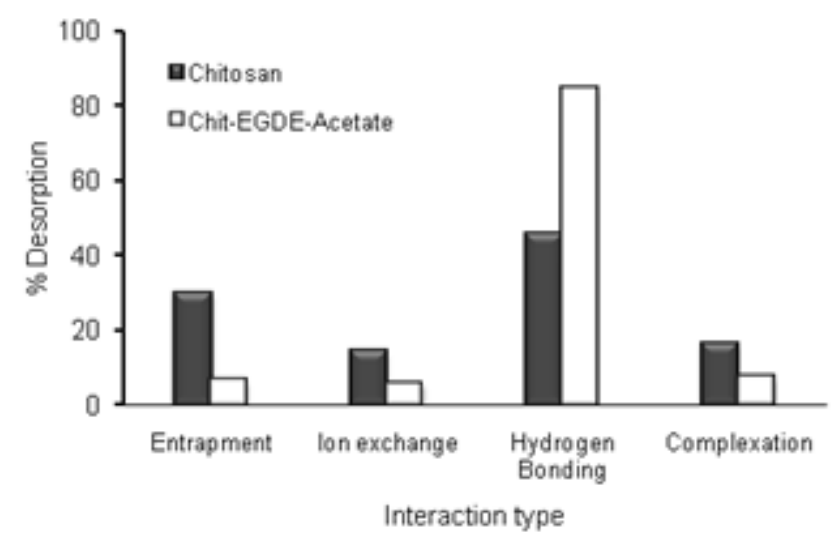

Fig 7. Interaction type of adsorption $\mathrm{Pb}$ (II) ions on Chitosan and Chit-EGDE-Acetate

\section{Adsorption Isotherm}

An adsorption isotherm provides a relationship between the solute concentration in the solution and the amount of metal adsorbed on the adsorbent when the two phases are at equilibrium. Fig. 6 shows adsorption $\mathrm{Pb}$ (II) ion on chitosan and Chit-EGDE-Acetate sorbent with various concentrations of metal ion in aqueous phase at equilibrium. Several models have been published to describe the adsorption isotherms. Freundlich and Langmuir adsorption isotherms are two types of models are most often used as a model of adsorption in solution.
Freundlich adsorption isotherm equation is an empirical equation that was used for adsorption on heterogeneous surfaces [33]. This equation is formulated as:

og $m=\log K_{f}+\frac{1}{n} \log C e$

where $\mathrm{m}$ is the number of metal ions adsorbed $\left(\mathrm{mmol} \mathrm{g}{ }^{-1}\right), \mathrm{Kf}\left(\mathrm{L} \mathrm{mol}^{-1}\right)$ is the adsorption distribution coefficient related to Freundlich adsorption capacity, and $\mathrm{n}$ is the Freundlich constants indicating heterogenity of the surface.

Langmuir adsorption isotherm equation is based on the assumption that adsorption process occurs homogeneously and often applied for a single layer adsorption. Langmuir equation is formulated as:

$\frac{C_{e}}{q_{e}}=\frac{1}{\mathrm{bK}}+\frac{1}{b} \mathrm{C}_{e}$

where $q_{e}$ is the amount of adsorbed per unit weight of adsorbent at equilibrium $\left(\mathrm{mmol} \mathrm{g}^{-1}\right), \mathrm{C}_{\mathrm{e}}$ is the adsorbate concentration in the aqueous phase at equilibrium (mmol L $\left.{ }^{-1}\right), b$ is the Langmuir adsorption capacity $\left(\mathrm{mmol} \mathrm{g}^{-1}\right), \mathrm{K}\left(\mathrm{L} \mathrm{mol}^{-1}\right)$ is the Langmuir adsorption equilibrium constants that can be used to determine the adsorption energy.

Table 2 showed the parameters of Freundlich and Langmuir isotherm adsorption. Adsorption $\mathrm{Pb}$ (II) ions on chitosan followed Freundlich adsorption isotherm with $\mathrm{R}^{2}=0.938$, while the adsorption of $\mathrm{Pb}$ (II) in ChitEGDE-Acetate agreed with the Langmuir isotherm adsorption with $R^{2}=0.979$. The adsorption capacity of $\mathrm{Pb}$ (II) in Chit-EGDE -Acetate was $0.789 \mathrm{mmol} \mathrm{g}^{-1}$ $\left(200.0 \mathrm{mg} \mathrm{g}^{-1}\right)$. It is greater than adsorption capacity of chitosan $0.778 \mathrm{mmol} \mathrm{g}^{-1}\left(166.7 \mathrm{mg} \mathrm{g}^{-1}\right)$. Chit-EGDEAcetate has amine group and also rich with carboxylate groups that is able to bind more $\mathrm{Pb}(\mathrm{II})$ ions.

The thermodynamic parameter for the adsorption process such as free energy $\left(\Delta G^{0}\right)$ can be calculated from Langmuir equilibrium constant using equation (6) [2-3].

$\Delta G^{0}=-R T$ In $\mathrm{K}$

where $\mathrm{R}$ is the general gas constant $\left(8.314 \mathrm{~J} \mathrm{~K}^{-1}\right.$ mole $\left.{ }^{1}\right), \quad T(K)$ is the temperature. Free energy for physisorption is generally lower than $-20 \mathrm{~kJ} \mathrm{~mol}^{-1}$, the physisorption together with chemisorption is at the range of -20 to $-80 \mathrm{~kJ} \mathrm{~mol}^{-1}$ and chemisortption is at range -80 to $-400 \mathrm{~kJ} \mathrm{~mol}^{-1}$ [3]. In Table $2, \Delta \mathrm{G}^{0}$ value for adsorption $\mathrm{Pb}(\mathrm{II})$ ions on chitosan is $-17.24 \mathrm{~kJ} \mathrm{~mol}^{-1}$ 
and for Chit-EGDE-Acetate is $-22.90 \mathrm{~kJ} \mathrm{~mol}^{-1}$, thus this adsorption involve physisorption and chemisorption simultaneously.

\section{Type Interaction of Adsorbent-Adsorbate}

Type of interaction $\mathrm{Pb}(\mathrm{II})$ ions with the adsorbent was studied by sequential desorption. As a desorption agent, water, $\mathrm{KNO}_{3} 0.1 \mathrm{M}, \mathrm{HNO}_{3} 0.1 \mathrm{M}$ and $\mathrm{Na}_{2}$ EDTA $0.1 \mathrm{M}$ were employed. Those desorption agents are responsible for adsorption of $\mathrm{Pb}(\mathrm{II})$ trough mechanism entrapment, ion exchange, hydrogen bonding and complexation, respectively. Results of desorption process are shown in Fig. 7. In the chitosan, desorption $\mathrm{Pb}(\mathrm{II})$ ions by water as much as $29 \%, 14 \%$ with $\mathrm{KNO}_{3}$, $45 \%$ with $\mathrm{HNO}_{3}$ and $16 \%$ with $\mathrm{Na}_{2}$ EDTA. This suggests that interactions between chitosan and $\mathrm{Pb}$ (II) ions were vary. Greatest interaction was hydrogen bonding between $\mathrm{Pb}(\mathrm{II})$ ions and amine groups. Entrapment interaction can occur between $\mathrm{Pb}$ (II) ions on chain of chitosan. Complexes interaction can happen between $\mathrm{Pb}$ (II) ions with amine group and hydroxyl group simultaneously. This data agree with Freundlich isotherm adsorption, with the assumption that adsorption occurs on heteregeneous surface.

Desorbed $\mathrm{Pb}(\mathrm{II})$ from Chit-EGDE-Acetate with water, $\mathrm{KNO}_{3}, \mathrm{HNO}_{3}$ and $\mathrm{Na}_{2} \mathrm{EDTA}$ was $6.7,5.8,84.9$ and $7.5 \% \mathrm{~Pb}(\mathrm{II})$, respectively. Type of interaction between the ions $\mathrm{Pb}(\mathrm{II})$ with Chit-EGDE-Acetate is dominated by hydrogen bonding between carboxylate groups and $\mathrm{Pb}(\mathrm{II})$ ions. This type of interaction is consistent with Langmuir isotherm adsorption. Interaction between $\mathrm{Pb}$ (II) ions and active sites on ChitEGDE-Acetate was dominated by one type of interaction, i.e. hydrogen bonds. This data is agreed with Langmuir isotherm adsorption, with the assumption that adsorption occurs on homogenous surface as observed by Ozkahraman the adsorption Brilliant Green on to chitosan graft copolymers [34].

\section{CONCLUSION}

Modification of chitosan by cross-linking with EGDE and grafting with chloroacetic acid produced Chit-EGDEAcetate that is insoluble in acids and have high adsorption capacity for $\mathrm{Pb}(\mathrm{II})$ ions. Modification was able to enhance the adsorption capacity for $\mathrm{Pb}$ (II). Adsorption process of $\mathrm{Pb}(\mathrm{II})$ ions on chitosan involved hydrogen bonding, entrapment, ion exchange and complex formation with relatively comparable percentage, while the adsorption of $\mathrm{Pb}(\mathrm{II})$ on Chit-EGDE-Acetate was dominated by hydrogen bonding between the adsorbent and adsorbate.

\section{ACKNOWLEDGEMENT}

This research was funded by the Competitive Research Grants Program of the Directorate General of Higher Education of the Republic of Indonesia, (DP2M DIKTI, No. 2881/H27/KU/2010). Thank for Prof. Dr. Shogo Shimazu from Chiba University, Japan for analysis with TG-DTA and Yosephin Dewiani Rahmayanti who helped to conduct this research.

\section{REFERENCES}

1. Ghaee, A., Shariaty-Niassar, M., Barzin, J., and Zarghan, A., 2012, Appl. Surf. Sci., 258 (19), 77327743.

2. Yan, H., Dai, J., Yang, Z., Yang, H. and Cheng, R., 2011, Chem. Eng. J., 174 (2-3), 586-594.

3. Sölener, M., Tunali, S., Özcan A.S., Özcan, A., and Gedikbey, T., 2008, Desalination, 223 (1-3), 308322.

4. Guibal, E., 2004, Sep. Purif. Technol., 38 (1), 4374.

5. Copello, G.J., Varela, F., Vivot, M., and Diaz, L.E., 2008, Bioresour. Technol., 99 (14), 6538-6544.

6. Miretzky, P., and Cirelli, A.F., 2009, J. Hazard. Mater., 167 (1-3), 10-23.

7. Liu, B., Wang, D., Xu, Y., and Huang, H., 2011, J. Mater. Sci., 46 (5), 1535-1541.

8. Chen, A., Liu, S.C., Chen, C.Y., and Chen, C.Y., 2008, J. Hazard. Mater., 154 (1-3), 184-191.

9. Dalida, P.M.L., Mariano, A.F.V., Futalan, C.M., Kan, C., Tsai W., and Wan, M., 2011, Desalination, 275 (1-3), 154-159.

10. Vieira, R.S., and Beppu, M.M., 2005, Adsorption, 11, 731-736.

11. Ramesh, A., Hasegawa, H., Sugimoto, W., Maki, T., and Ueda, K., 2008, Bioresour. Technol., 99, 3801-3809.

12. Zhang, Q., Deng, S., Yu, G., and Huang, J., 2011, Bioresour. Technol., 102 (3), 2265-2271.

13. Suguna, M., Kumar, S.S., Reddy, A.S., Boddu, V.M., and Krishnaiah, A., 2011, Can. J. Chem. Eng., 89 (4), 833-843.

14. Santoso, U.T., Umaningrum, D., Irawati, U., and Nurmasari, R., 2008, Indo. J. Chem., 8 (2), 177183.

15. Oshita, K., Seo, K., Sabarudin, A., Oshima, M., Takayanagi, T., and Motomizu, S., 2008, Anal. Bioanal. Chem., 390, 1927-1932.

16. Katarina, R.S., Takayanagi, T., Oshita, K., Oshima, M., and Motomizu, S., 2008, Anal. Sci., 24 (12), 1537-1544.

17. Sabarudin, A., Noguchi, O., Oshima, M., Higuchi, K., and Motomizu, S., 2007, Microchim. Acta, 159 (3-4), 341-348. 
18. Kocak, N., Sahin, M., Arslan, G., and Ucan, H.I., 2012, J. Inorg. Organomet. Polym., 22 (1), 166-177.

19. Grisdanurak, N., Akewaranugulsiri, S., Futalan, C.M., Tsai, W., Kan C.C., Kan, C.C., Hsu, C.W., and Wan, M.W., 2012, J. Appl. Polym. Sci., 125 (S2), 132-142.

20. Tirtom, V.N., Dincer, A., Becerik, S., Aydemir, T., and Celik A., 2012, Chem. Eng. J., 197, 379-386.

21. Wang, L., Li, Q., and Wang, A., 2010, Polym. Bull., 65 (9), 961-975.

22. Farag, S., and Kareem, S.S.A., 2009, Carbohydr. Polym., 78 (2), 263-267.

23. Abreu, F.R., and Campana-Filho, S.P., 2005, Polímeros, 15 (2), 79-83.

24. Buhani, Suharso, and Sumadi, 2010, Desalination, 259 (1-3), 140-146.

25. Li, N., and Bai, R., 2005, Ind. Eng. Chem. Res., 44 (17), 6692-670.

26. Dong, Y., Xu, C., Wang, J., Wang, M., Wu, Y., and Ruan, Y., 2001, Sci. Chin. Chem., 2 (44), 216-224.
27. Van de Velde, K., and Kiekens P., 2004, Carbohydr. Polym., 58 (4), 409-416.

28. Zhang, Y., Xue, Y., Gao, R., and Zhang, X., 2005, Carbohydr. Res., 340 (11), 1914-1917.

29. Jiao, T.F., Zhou, J., Zhou, J.X., Gao, L.H., Xing, Y.Y., and Li, X.H., 2011, Iran. Polym. J., 20 (2), 123-136.

30. Santoso, U.T., Nurmasari, R., Umaningrum, D., Santosa, S.J., Rusdiarso, B., and Siswanta, D., 2012, Indo. J. Chem., 12 (1), 35-42.

31. Zhang, J., Zhang, Y., Li, R., and Pan, Q., 2012, Indian J. Chem. Technol., 19 (3), 161-166.

32. Ho, Y.S., and McKay, G., 1999, Process. Biochem., 34 (5), 451-465.

33. Erosa, M.S.D., Medina T.I.S., Mendoza, R.N., Rodriguez, M.A., and Guibal, E., 2001, Hydrometallurgy, 61 (3), 157-167.

34. Ozkarahman, B., Bai, A., Acar, I., and Guchu, G., 2011, Clean-Soil, Air, Water, 39 (11), 1001-1006. 